\title{
ARCHAEOLOGY IN MUSEUMS IS ESSENTIAL!
}

\section{Susanne Thedéen}

Gotland Museum

Strandgatan 14, 62156 Visby, Sweden

susanne.thedeen@gotlandsmuseum.se

Swedish museums now operate within an increasingly professional and complex sphere, expanding way beyond the traditional role of a cultural institution. Our status of Länsmuseum (county museum) means that we cannot envisage any great increase in subsidies from the state or local government, so other sources of revenue such as our contracted assignments, along with admission fees, retail sales from our shop, external projects and sponsorship via strategic partnership are all of great significance to our development of museum activities.

In fact, offering our professional services through contracted assignments is an important income-generating activity for the museum as a whole. A museum is of course fully entitled to opt out of this source and find other means of funding, but Gotland Museum regards commercial activities in general, including contract archaeological excavations, as one of the most important elements of museum operations. This is for two reasons. Firstly, contracted assignments generate earned income which boosts the museum's economy. Secondly, they contribute to the expansion of our knowledge bank. The museum's contracted assignments focus primarily on archaeology and building preservation. But Gotland 
Museum also undertakes and develops revenue-generating activities in other fields, such as exhibitions, education, etc.

Geographically, we mainly operate on Gotland, where contract archaeology has so far encountered no more than moderate competition. Competition from local actors is limited and thresholds for companies from the mainland make it difficult to get established and make any profit out of enterprises on Gotland. The market as such is not very extensive, since major land development projects on Gotland are few. Thus, we have not yet had to face the difficult dilemma experienced by other museums. On the other hand, neither have we attempted to set up operations on the mainland, where our prospects of viability are poor, since thresholds are too high and we are too limited, with specialist knowledge primarily related to Gotlandic conditions.

Contract archaeology is closely linked to economic fluctuations while income varies over time, the cost of maintaining permanent staff is constant. This leads to great economic uncertainty and the fluctuating income needs to be supplemented by and adapted to other sources of income. One feasible approach for museums would be to combine projects for research and furthering knowledge with contract archaeology. In this connection, the new Museum Act is favourable in that it emphasizes that museums should contribute to research and furthering knowledge. Museums should take this very seriously and develop strategies for how we are to comply with them and how we should interpret the content of 'contribute to'.

Contract archaeology is an important feature in Gotland Museum's operations, and it is utilized in our collection management, in our activities with the public at large and not least in our furthering of knowledge. Our archaeologists also work with public service and education, where part of their employment is funded by subsidies from the government-based Cultural Collaboration Model (20II). This ensures that the knowledge gained from contract archaeology is made available to museum visitors through lectures, guided tours and organized walks.

On a national level, where competition is fierce, the situation is quite different. But to begin with, museums do not necessarily have to carry out contract archaeology as a commercial enterprise. It is quite possible to work with different sources of revenue within museum management, but entrepreneurship must be 'a separate entity'. Furthermore, conducting contract archaeology as a commercial enterprise does not necessarily entail loss of knowledge per se. Organization can well be formed so that knowledge is transferred between the commercial enterprise and the museum. The greatest problem lies in the situation whereby a museum abstains from any form of contract archaeology due to harsher compe- 
tition and lack of profit. This situation leads to a need of institutionalized arenas, such as universities or colleges for spreading knowledge. Another conceivable actor would be Länsstyrelserna (the County Administrative Boards).

These new prerequisites place new and different demands both on leadership and on economic know-how within the museum sector. This is one key to success for new museum archaeology. 